\title{
МОДЕРНІЗАЦІЯ СИСТЕМИ АВТОМАТИЗОВАНОГО КЕРУВАННЯ ВАКУУМ-АПАРАТОМ ПЕРІОДИЧНОЇ ДІЇ ЦУКРОВОГО ВИРОБНИЦТВА НА БАЗІ ТЕХНІЧНИХ І ПРОГРАМНИХ ЗАСОБІВ УКРАЇНСЬКОГО ВИРОБНИЦТВА
}

\author{
Скаковський Ю. М. ${ }^{1}$, Бабков А. В. ${ }^{2}$, Мандро О. Ю. ${ }^{3}$ \\ 1,2,3 Одеська національна академія харчових технологій, Одеса, Україна \\ ORCID: ${ }^{10000-0003-4888-4469 ;}{ }^{2}$ 0000-0002-9167-7804 \\ E-mail: 1yurysk@ukr.net, ${ }^{2}$ babandval@gmail.com, ${ }^{3}$ mandro.helen@gmail.com
}

Copyright (C) 2018 by author and the journal “Automation technologies and business - processes. This work is licensed under the Creative Commons Attribution International License (CC BY). http://creativecommons.org/licanses/by/4.0

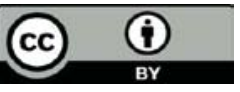

DOI:

Анотація: Розглядаються технічні рішення з розробки системи автоматизованного керування (САК) вакуумапаратом (BA) періодичної дї иукрового виробництва. Наведений аналіз відомих рішень із розробки аналогічних систем. Проведені лабораторні дослідження програми керування варкою иукрового утфелю у ВА, щуо була складена FBD подібною мовою програмування контролера МIК52 українського виробництва. Складена спрощена модель ВА як об'єкта керування. Імітаційне моделювання САК проводилось на спеціалізованому стенді із застосуванням промислових контролерів та програмних засобів українського виробниитва, в тому числі SCADA-системи «IHДЕЛ». Для зв'язку програмованого контролера, регулятора та комп'ютера використаний перетворювач інтерфейсів MODBUS RTU - USB типу БПI-52. Наведені результати моделювання САК у виді параметричних та часових діаграм, аналіз котрих дозволяє зробити висновки про працездатність розроблених програм керування. За результатами лабораторних досліджень було створено промисловий варіант автоматизованого робочого місия (АРМ) оператора $B A$, котрий був впроваджений на діючому иукровому заводі. Вправаджене АРМ оператора, окрім контролерів в щзиті автоматизації та комплекту промислового комп'ютера, додатково містить пульт керування для реалізацї деяких функиій оператора у дистаниійному режимі. Проведені промислові іспити підтвердили працездатність запропанованих технічних рішень, котрі було розроблено за результатами відповідних лабораторних досліджень та покладено в основу реалізованої промислової модифікації АРМ оператора ВА. Крім того, за отриманими результатами були визначені напрямки подальших досліджень САК процесом варки иукрових утфелів у ВА.

Abstract: Technical solutions for batch pan (VA) automated control system (ACS) development for sugar processing are considered The analysis of known solutions for similar systems improvement is presented. Laboratory studies were conducted of a program for the preparation of sugar massecuite in VA compiled in the FBD language, similar to the programming language for the Ukrainian MIC52 controller. A simplified model of the VA as a control object has been compiled. Simulation of ACS at specialized stand using industrial controllers and programs of Ukrainian production, including the SCADA-system "INDEL" was carried out. To connect the programmable controller, regulator and computer the converter of interfaces MODBUS RTU - USB type BPI-52 has been used. The results of ACS simulation in the form of parametric and time diagrams are presented, the analysis of which allows us to draw conclusions about the operability of the developed control programs. According to the results of laboratory tests, an industrial version of the VA operator's workstation (AWP) was created, which was implemented at the existing sugar plant. In addition to the controllers in the automatic control switchboard and the industrial computer kit, the implemented operator's AWP also has a remote to perform some of the operator's functions remotely. Industrial tests that were carried out have confirmed the operability of proposed technical solutions that have been developed on the basis of the relevant laboratory tests and formed the basis of the implemented industrial modification of VA operator's AWP. In addition, according to the results obtained, the further studies directions ACS cooking sugar massecuite in VA were determined. 
Ключові слова: Система автоматизованого керування (САК), автоматизоване робоче місце (АРМ) оператора, мікропроцесорний контролер, програма керування, вакуум-апарат періодичної дії (ВА), продуктове відділення, цукровий завод.

Keywords: Automated control system (ACS), operator's workstation (AWP), microprocessor-based comptroller, control program, batch pan (VA), grocery department, sugar plant.

\section{Вступ}

В Одеській національній академії харчових технологій в межах госпдоговірної тематики виконуються роботи із надання науково-технічної допомоги при модернізації систем автоматизації для підвищення ефективності їх функціонування на Красилівському бурякоцукровому заводі (Хмельницької області). Створена багаторівнева автоматизована система керування технологічними процесами (АСКТП) бурякоцукрового виробництва, котра включає в себе мережу автоматизованих робочих місць (АРМ) операторів основних технологічних ділянок, АРМи диспетчера, головного технолога і директора на базі мікропроцесорних контролерів, комп'ютерів та локальної мережі на базі технології Ethernet [1]. На теперешній час, в зв'язку із реконструкцією технологічної схеми продуктового відділення 3 додаванням нового вакуум-апарата періодичної дії (BА) до складу групи відповідних апаратів, котрі уварюють утфель першого продукту, виконуються роботи 3 модернізації системи автоматизації вакуум-апарата періодичної дії, що базується на використанні технічних і програмних засобів українського виробництва.

\section{Аналіз літературних джерел і постановка проблеми}

Уварювання цукрових утфелів першого продукту здійснюється в модернізованому ВА, із примусовою циркуляцією для інтенсифікації процесів кристалізації. Як вихідний розчин використовується сироп із клеровкою (розчин цукру нетоварної якості) та відтоки утфелю першого продукту, що центрифугується, (біла та зелена патоки). Як гріючий агент, використовується, згідно із тепловою схемою заводу, вторинна пара другого корпусу випарної станції (ВС), котра характерізується відносно низьким потенціалом (0,06 - 0,07 МПа). Уварювання утфелю здійснюють під розрідженням, за допомогою регулюючого органу (РО) на вакуумпроводі до ВА, котрий призначено для керування температурою в просторі ВА.

Процес отримання утфелю першого продукту (кристалізації) традиційно розділяють на наступні етапи (стадії): набір (наповнення) ВА сиропом (вище рівня розташування гріючої камери), згущення його до певного стану, коли потрібно заводити у ВА цукрову пудру для створення центрів кристалізації; нарощування кристалів, згущення утфелю, вигрузку звареної маси в мішалку та пропарювання ВА [2].

У практиці роботи цукрових заводів перші два етапи отримання утфелю здійснюють однотипно, але етап створення центрів кристалізації («заводка») є найбільш відповідальним [3]. Подальші етапи: нарощування кристалів та згущення утфелю, як і перші, виконані в неоптимальний спосіб, зазвичай призводять до збільшення часу циклу уварювання, витрати пари, що гріє, а іноді і до погіршення якості отриманих кристалів (цукру). Виходячи 3 цього, очевидним є потреба в розробці системи автоматизації управління описаного процесу.

Найбільш поширений метод проведення всіх етапів отримання утфелю $є$ робота з періодичним введенням у ВА сиропу (вихідного розчину) - так звані «підкачки», що викликано високою густиною вихідних розчинів та утрудненням використання виконавчих механізмів із неперервно діючими регулюючими органами.

Найбільш відомі розробки систем автоматизованого керування (САК) ВА, котрі були впроваджені починаючи з 70х років XX ст., як в НВО «Харчопромавтоматика» (м. Одеса), так і в НВО «Цукор» (м. Київ). Перші, створювались на основі вимірювання рівня та, так званої, структурної в’язкості (консистенції) продукту у ВА, 3 врахуванням необхідності вимірювання (із використанням ротаційного віскозиметра) характеристик двохфазного середовища: кристалів цукру і міжкристального розчину. Другі, пропонували використовувати для контролю концентрації продукту, так звану температурну депресію, тобто різницю між температурою кипіння цукрового розчину та розчинника, яка зростає зі збільшенням концентрації речовини (цукру), що розчинена, та зовнішнього тиску у ВА.

Розробка, виготовлення та впровадження ротаційного віскозиметра (Піменов В.В., Ковбасюк П.П.) дозволило вимірювати консистенцію $M$ продукту за всім діапазоном змін вродовж всього циклу уварювання. Вимірювання рівня $H$ двохфазного продукту здійснювались за допомогою п'єзометричного методу із використанням дифманометра. При цьому, перші варіанти пристроїв САК створювались на базі елементів «Логіка-Т» і приладу КС3, в котрих програма варки - задана програмна залежність $H=H(M)$, була записана на полі кругової діаграми в полярних координатах, та зчитувалась за допомогою фотодатчиків і передавалась, за допомогою провідних ліній зв'язку для виконання, у відповідний керуючий пристрій.

У період актуальності використання пневматичних елементів і систем керування на цукрових заводах, до повсюдного застосування мікропроцесорних контролерів, у НВО «Харчопромавтоматика» був розроблений та впроваджений на багатьох цукрових заводах пневматичний варщик утфелю, котрий містив в своєму складі пневматичний програмний регулятор (Резник К.С, Зелезецький В.Л. і Вітвицький В.Д.). У наступному періоді, під час широкого впровадження мікропроцесорних контролерів, великий вклад у розробку САК варки утфелю на базі мікропроцесорних програмованих контролерів вніс Вітвицький В.Д., який суттєво вдосконалив, як програму варки, так і конструкцію ротаційного віскозиметра, разом із схемою блоку живлення та перетворення сигналів до нього. 
Використання нових конструкцій ротаційного віскозиметра, на нашу думку, має суттєву перевагу над іншими методами контролю консистенції продукту в циклі його варки. Адже відомий метод вимірювання току навантаження двигуна мішалки, котра здійснює примусову циркуляцію у ВА, показує значно меншу чутливість вимірювання, а використання метода контролю температурної депресії, кондуктометра та інших приладів не дозволяє проводити точне вимірювання в усьому діапазоні зміни консистенції двофазного продукту в циклі його варки.

Таким чином, для створення модернізованої САК процесом варки утфелю потрібно було, використовуючи досвід останніх розробок, враховуючи досвід робітників служби КВП і А заводу з роботи і обслуговування мікропроцесорних контролерів та регуляторів фірми «МІКРОЛ» (м. Івано-Франківськ), а також SCADA-системи «ІНДЕЛ», котра також являє собою сучасний програмний засіб вітчизняного виробництва, створений на підприємстві «Інфотехпром» (м. Полтава), який використано в більшості АРМ операторів на інших ділянках заводу, розробити АРМ оператора варщика для нового ВА.

\section{Мета і завдання дослідження}

Мета й завдання передпроєктних досліджень для створення АРМ оператора полягала в зборі вихідних даних про необхідну для подання інформацію, бажану форму подання цієї інформації, визначення необхідної періодичності опитування даних, котра виключала би втрату інформації, а також в проведенні аналізу можливих варіантів структури системи, алгоритмічних рішень, вибору технічних та програмних засобів для іх реалізації з остаточним узгодженням пропонованої концепції із технічним керівництвом заводу. Крім того отримані результати розробки потрібно оформити у вигляді технічної документації, передати іiі спеціалістам ЗАМОВНИКА, та надати науково-технічну допомогу для впровадження САК на заводі.

За узгодженням зі спеціалістами ЗАМОВНИКА перелік завдань виключає автоматизацію допоміжних операцій (ПУСК - ЗУПИНКА), тому що ці операції оператор виконує в дистанційному режимі з розробленого пульта ВА. Таким чином, створюється автоматизована система керування, а не автоматична. Варіант аналогічної автоматичної системи був розроблений і впроваджений НBО «Харчопромавтоматика» на базі керуючої мікро ЕОМ (CM 1800) на Одеському та Московському цукрорафінадних заводах, ще в 1987-88 роках. Але зазначенй варіант САК не отримав розповсюдження через складність обслуговування технічних засобів, і в подальшому не використовувався в цукровій промисловості.

Таким чином, основним завданням дослідження було розробити алгоритм і програму варки утфелю 3 використанням мови програмування для мікропроцесорного контролера МІК52 та дослідити ії роботу в лабораторних умовах, і за отриманням успішного результату, на базі зазначеного контролера створити АРМ оператора 3 використанням SCADA-системи «ІНДЕЛ», що дозволить у подальшому включити цей АРМ у склад АСКТП, тобто підключити до їснуючої заводської інформаційної мережі.

\section{Методи та матеріали досліджень}

Під час виконання передпроєктних досліджень використовувались методи порівняльного аналізу варіантів структури системи із застосуванням різних технічних та програмних засобів, з урахуванням факторів, що викладені вище, стосовно попередньо створених на заводі систем керування. Остаточні технічні рішення приймалися на основі критерію «ціна-якість» із перевіркою працездатності системи методами імітаційного моделювання. У процесі імітаційного моделювання був використаний лабораторний стенд, котрий було оснащено промисловими контролерами: МІК52, МІК112, аналоговими задатчиками РЗД-22 (зі струмовим виходом 4,..,20 мА), дискретними задатчиками $(0 ; 24$ В), блоком перетворення інтерфейсів БПІ-52, комп'ютером із інстальованим програмним забезпеченням, зокрема: драйвером для БПI-52, SCADA-системою «IНДЕЛ» 3 драйвером MODBUS RTU, котрий надає можливості створити інформаційний шлюз між комп'ютером та контролерами за допомогою двохпровідного інтерфейсу RS-485.

Для оцінювання оптимальної періодичності опитування даних, котра виключала би втрату інформації, було застосовано відому інженерну методику, котра базується на наслідку із теореми Котельникова.

\section{Результати дослідження}

Основні остаточні технічні рішення. Структура САК варки утфелю, що розробляється, включає об'єкт керування (ОК) та керуючий пристрій. САК можна представити у вигляді схеми, котра наведена на рис. 1. Позначення на схемі:

Н - рівень продукту у ВА, \%;

М - структурна в'язкість продукту у ВА, \%;

Тва - температура в просторі ВА, ${ }^{\circ} \mathrm{C}$;

Рп - тиск пари, що гріє, МПа;

$\mathrm{U}_{1}$ - положення регулюючого органу, що керує подачею вихідного розчину у ВА, \%;

$\mathrm{U}_{2}$ - положення регулюючого органу, що керує зв'язком простору ВА з магістраллю вакууму, \%;

$\mathrm{f}_{1}, \mathrm{f}_{2}$ - вектори неконтрольованих збурень. 


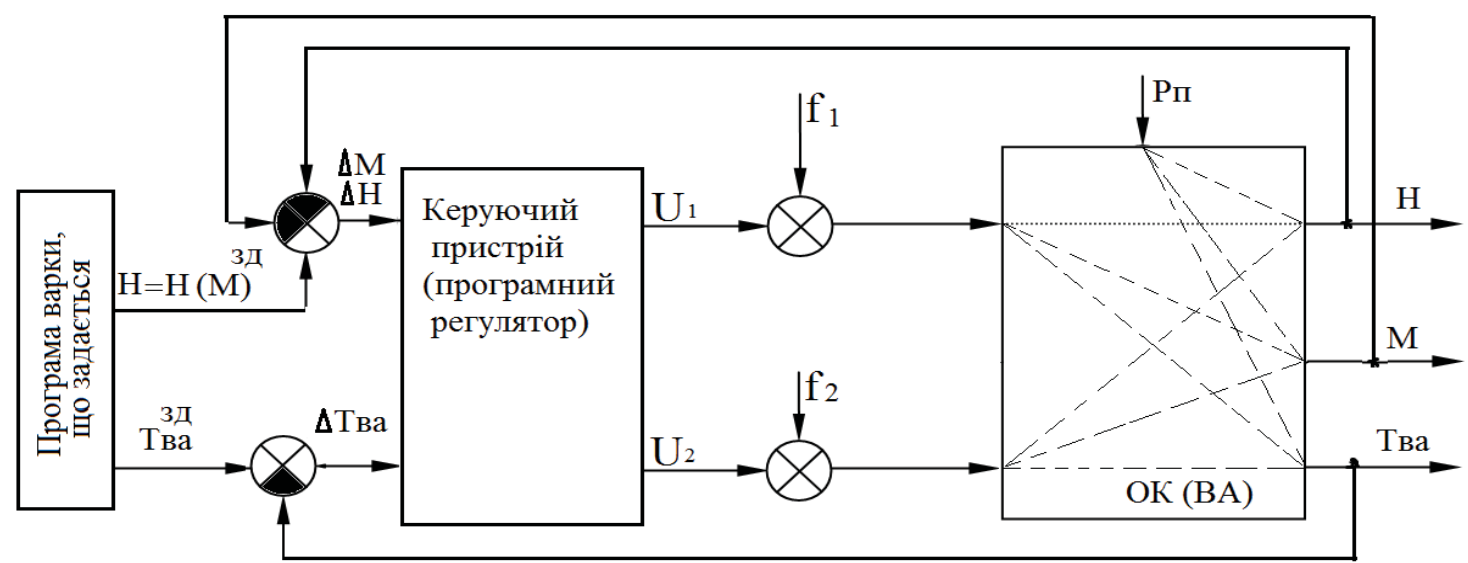

Рис. 1 - Структурна схема САК варки утфелю

ВА як об'єкт керування має ряд особливостей. У ньому присутні перехресні зв'язки змінних та велика кількість збурюючих впливів, автоматичний контроль значної кількості котрих є дуже утрудненим, оскільки пов'язаний із якісним складом вихідних розчинів та продукту у ВА, що уварюється. Суттєвий вплив на вихідні змінні оказує тиск гріючої пари, що йде як вторинна із другого корпусу ВС. Крім того, відомо, що в циклі варки ВА витрати пари, котра гріє, є нерівномірними і залежними від стадії варки та конструктивних особливостей ВА. В [4] наведені подібні залежності, котрі були отримані експериментально, для конкретної модифікації ВА продуктового відділення цукрорафінадного заводу, але розповсюджувати їх для всіх аналогічних конструкцій ВА бурякоцукрового виробництва $є$ недоцільним без дослідження індивідуальних характеристик ВА та процесів варки в них утфелю. У тому ж джерелі наведені рекомендації щодо зменшення коливань тиску гріючої пари для групи ВА періодичної дії, котра базується на оптимальном керуванні моментом запуску в роботу кожного окремого апарата в групі. Проведення аналогічних експериментальних досліджень для кожного ВА є достатньо витратними та технічно складними.

Відомі також дослідження з пошуку оптимальних змін заданої температури в просторі ВА в процесі уварювання утфелю у ВА з метою скорочення загального часу циклу варки утфелю. В тойже час, на ці залежності також суттєво впливають індивідуальні особливості конструкції ВА та складу вихідних продуктів, тому оцінювання параметрів цих залежностей доцільно проводити експериментально під час роботи САК, що здійснює автоматичну варку.

3 урахуванням вище зазначеного, було прийняте рішення в даному дослідженні зосередитись на розробці саме програми варки утфелю у ВА, реалізації цієї програми в середовище програмування контролера МІК52 та промислового комп'ютера із SCADA-системою «ІНДЕЛ» для створення АРМ оператора-варщика. Провести лабораторні та промислові дослідження працездатності розробленої системи автоматичної варки утфелю.

Дослідження згаданих вище залежностей між змінними процесу варки у ВА доцільно проводити на діючому ВА, котрий керується автоматично у складі АРМ оператора-варщика.

За результатами передпроєктних досліджень була запропонована й узгоджена із ЗАМОВНИКОМ програма варки у вигляді залежності $H=H(M)$, методика отримання котрої традиційно використовується в САК варкою утфелів. Побудова такої програми, оптимальної з точки зору якості отриманих кристалів цукру та мінімального часу циклу уварювання аналітичними методами стикається із проблемою багатофакторності збуджуючих впливів, автоматичний контроль значної кількості котрих $є$ дуже утрудненим. Тому традиційно використовуються експериментальні експертні методи. Вид розглянутої залежності визначають за результатами попередніх уварювань продуктів в аналогічних ВА, а опорні точки визначають та уточнюють за результатами декількох варок, що проводить найдосвідчений оператор-варщик, за успішністю отриманих кінцевих результатів. Таким чином, програма варки для нового ВА була розроблена у вигляді допоміжної форми для налаштування, в складі АРМ оператора-варщика (рис. 2).

У перелік технічних засобів, з котрих складається АРМ, окрім датчиків температури, рівня та структурної в'язкості продукту у ВА, виконавчих механізмів із $\mathrm{PO}$, що реалізують керуючи впливи $\mathrm{U}_{1}$ та $\mathrm{U}_{2}$, програмованого контролера та промислового комп'ютера 3 SCADA-системою, входить пульт керування із органами дистанційного керування та приладами, що показують основні змінні та сигналізують про стани режиму «заводки» пудри у ВА та етап закінчення варки. Крім того, розробляється щит оператора із приладами, що показують поточні значення допоміжних змінних, органів дистанційного керування та звукової сигналізації.

Режим керування подачею вихідного розчину у ВА є двохпозиційним: за відкриттям РО (100\%) - порція вихідного розчину подається у ВА, за закриттям РО (0\%) - провадиться згущення розчину в ВА внаслідок випаровування вологи 3 нього. При цьому, пара подається в гріючу камеру за повністю відкритою паровою засувкою впродовж всього циклу варки. Використання інших режимів керування нею недоцільно, внаслідок відносно невеликого тиску зазначеної пари, що гріє, із ВC. 
Серед органів дистанційного керування, котрі розміщено на пульті ВА, слід виділити насамперед тумблери Т1 (НАБІР) та Т2 (ПІДКАЧКА), а також тумблери, котрі формують склад вихідного розчину, що подається через гребінку (колектор вихідних розчинів) та $\mathrm{PO}\left(\mathrm{U}_{1}\right)$ в ВА.

Дії оператора під час керування циклом варки полягають у наступному. Після пропарювання апарата й виконання допоміжних операцій із включення ВА у роботу в дистанційному режимі, варщик включає тумблер Т1. Після цього, програма автоматичної варки здійснює керування РО $\left(\mathrm{U}_{1}\right)$. На етапі НАБІР апарат наповнюється вихідним розчином до рівня h1, після чого здійснюється згущення продукту у ВА, зі стабілізацією рівня h1, шляхом підкачки порцій свіжого розчину. Консистенція продукту зростає після закриття РО (внаслідок випаровування вологи) і зменшується під час відкриття РО. Протилежні зміни, вочевидь, здійснюються відносно рівня продукту у ВА. За досягненням консистенції продукту $\mathrm{M}=$ Мзав, оператор отримує звуковий, світловий сигнали, а також повідомлення на екрані комп’ютера про необхідність перевірки стану готовності ВА до «заводки» пудри (центрів кристалізації). Оператор вимикає Т1 і вводить в ВА цукрову пудру. Після перевірки стану продукту, в тому числі 3 використанням органолептичних методів, вмикає Т2 (ПІДКАЧКА). Програма керує РО і забезпечує реалізацію процесу так званої першої глибокої підкачки, що призводить до збільшення рівня у ВА та зменшення консистенції до точки М2, після чого реалізується режим стабілізації консистенції зі зростанням рівня у ВА до значення h2. На цьому етапі починають формуватися кристали цукру навколо дрібнодисперсних кристалічних центрів, тобто окремих часток попередньо «заведеної» цукрової пудри. Далі починається стадія «зростання кристалу», відображення котрої навелено на рис. 2 від точки 3 координатами (x1, y1) до точки (x5, y5), програма реалізує керування процесом із використання кусочнолінійної функції. Після досягнення точки (x5, у5), що відповідає готовності апарату, тобто стан апарату відповідає повному робочому рівню готового продукту (утфелю) у ВА, оператор отримує звуковий та світловий сигнали, а також повідомлення про закінчення варки на екрані АРМ. Оператор перевіряє стан продукту у ВА, i, за підтвердженням готовності, здійснює вивантаження утфелю в мішалку, виконує необхідні допоміжні операції та пропарює апарат для початку наступного циклу варки.

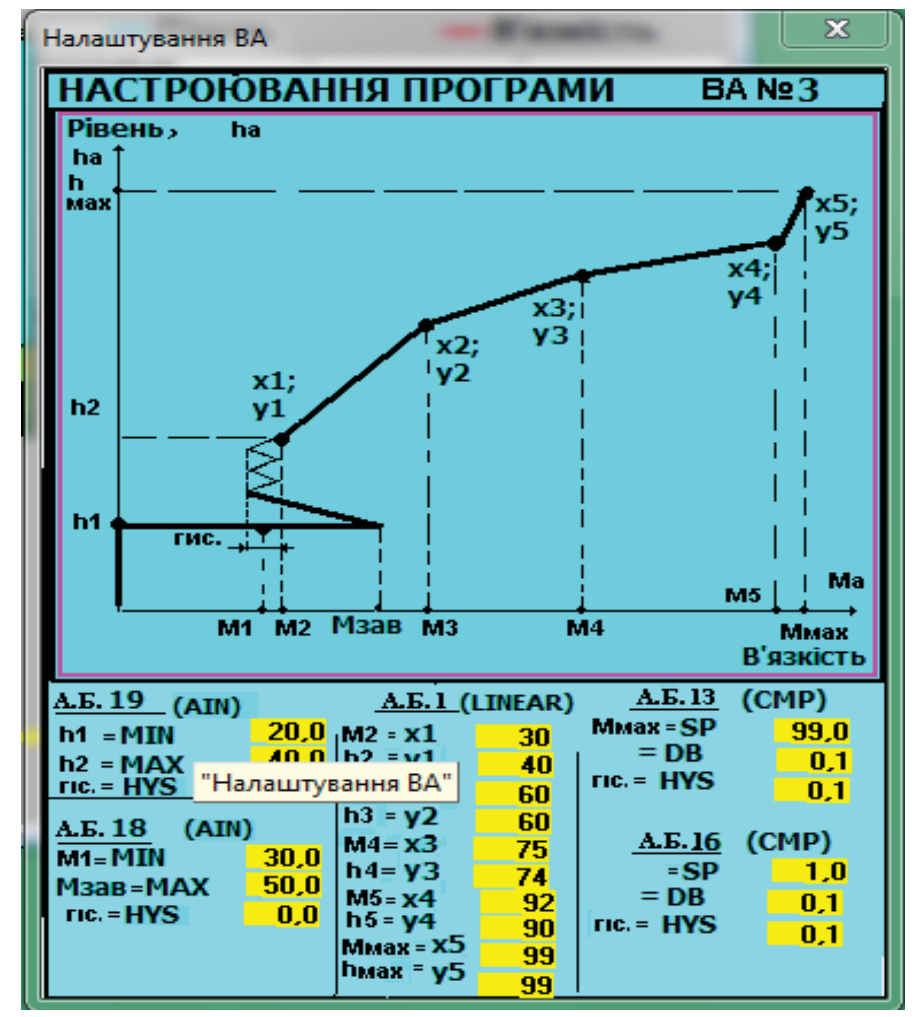

Рис. 2 - Допоміжна екранна форма для налаштування програми варки утфелю

Кожна з наведених на екранній формі, призначеній для налаштування програми варки утфелю, (див. рис. 2) опорних точок, може бути уточнена в процесі налаштування відповідної програми, шляхом введення скоригованих значень.

Реалізація керуючої програми в контролері МІК52 виконана FBD подібною мовою «а», призначеною для програмованих контролерів фірми «МІКРОЛ». Імітаційне моделювання для перевірки працездатності складеної програми, виконувалося також у середовище програмування відповідного контролера, при цьому. канали ОК: $\mathrm{U}_{1}->$ $\mathrm{H} ; \mathrm{U}_{1} \rightarrow \mathrm{M}$ можна розглядати як інтегруючі ланцюги із різними знаками та чисельними коефіцієнтами, котрі відповідають процесам підкачки порції «свіжого» розчину та випарюванню вологи з розчину у ВА. 
Структура програми, котра була розроблена для дослідження, наведена на рис. 3, та включає в себе фрагмент керуючої програми (зверху) і програму моделі (знизу), що імітує наведені вище канали ОК.

Початковий вид основної екранної форми оператора за моделюванням проведення стадій набора продукту у ВА та згущення наведено на рис. 4 а, а відповідно, за моментом «заводки» кристалу - 4 б.

Масштаб часу в моделі ОК та реальному ОК має співвідношення 1:3.

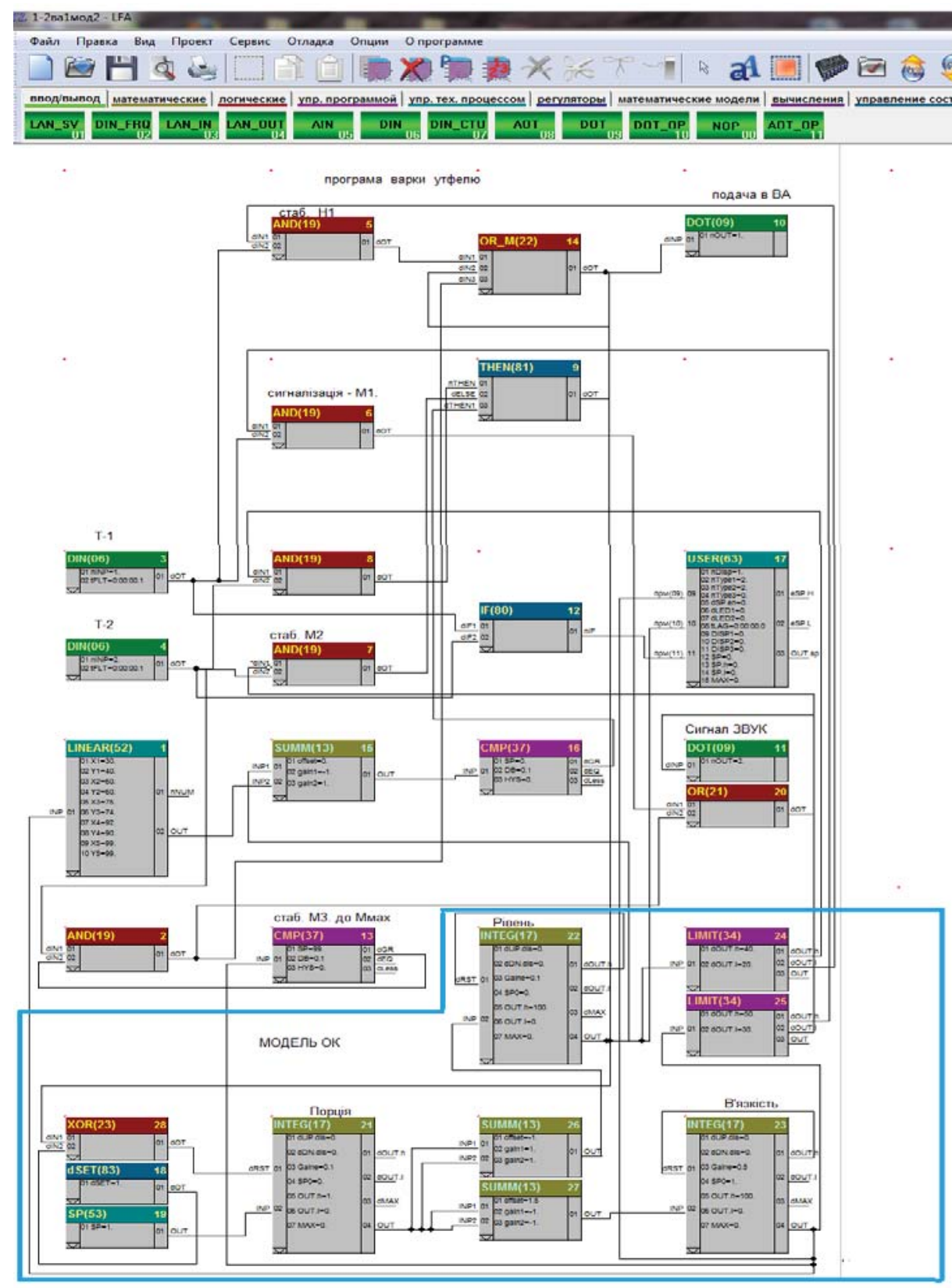

Рис. 3 - Програма, що складена мовою «व», для імітаційного моделювання поведінки САК процесу уварювання утфелю у ВА 


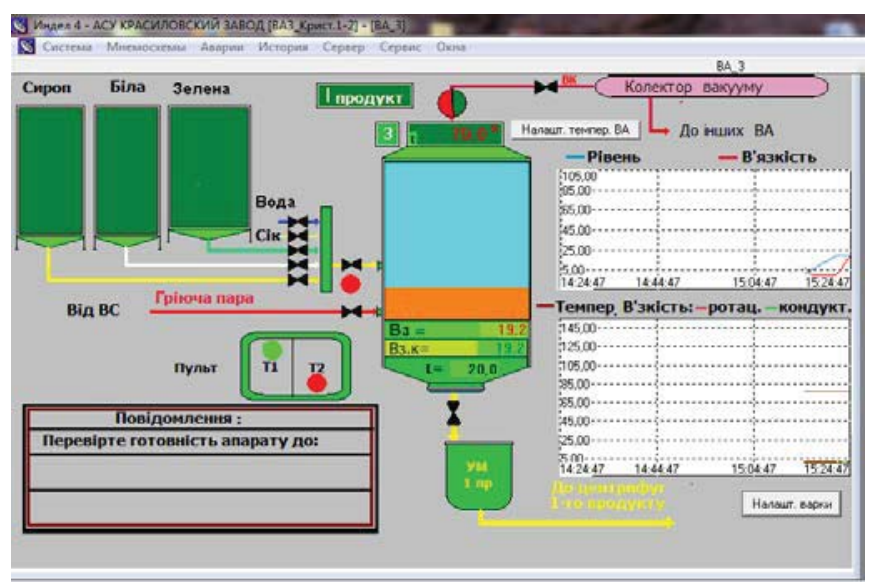

a)

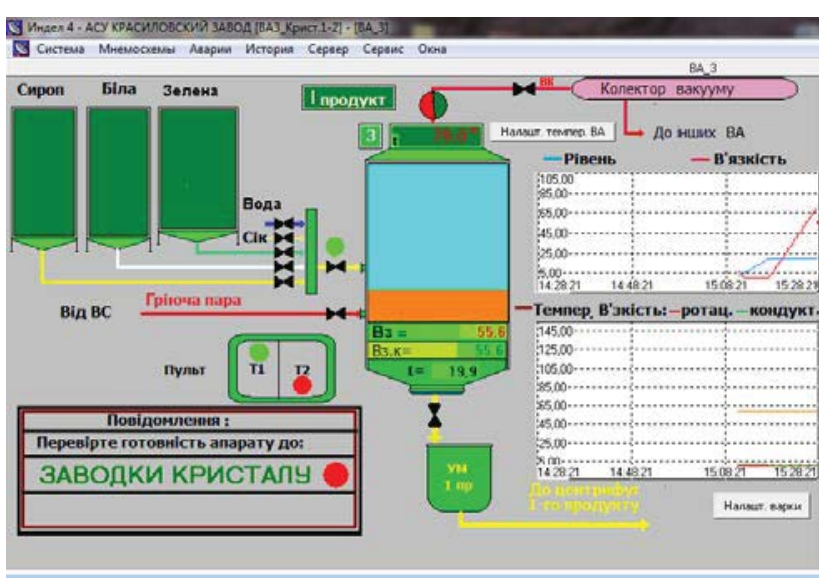

б)

Рис. 4 - Основна екранна форма АРМ оператора-випарщика на стадіях:

a) - набор та початок згущення; б) - «заводка» пудри в ВА

Найбільш зручною формою для аналізу отриманих результатів роботи моделі САК уварювання утфелю та порівняння із заданою програмою є параметричний графік (діаграма), котрій можна отримати за моделюванням у налагодженій SCADA-системі «ІНДЕЛ». Відтак для етапів набору у ВА, «заводки» цукрової пудри, формування та початку зростання кристалу -отримана діаграма має вигляд як на рис. 5.

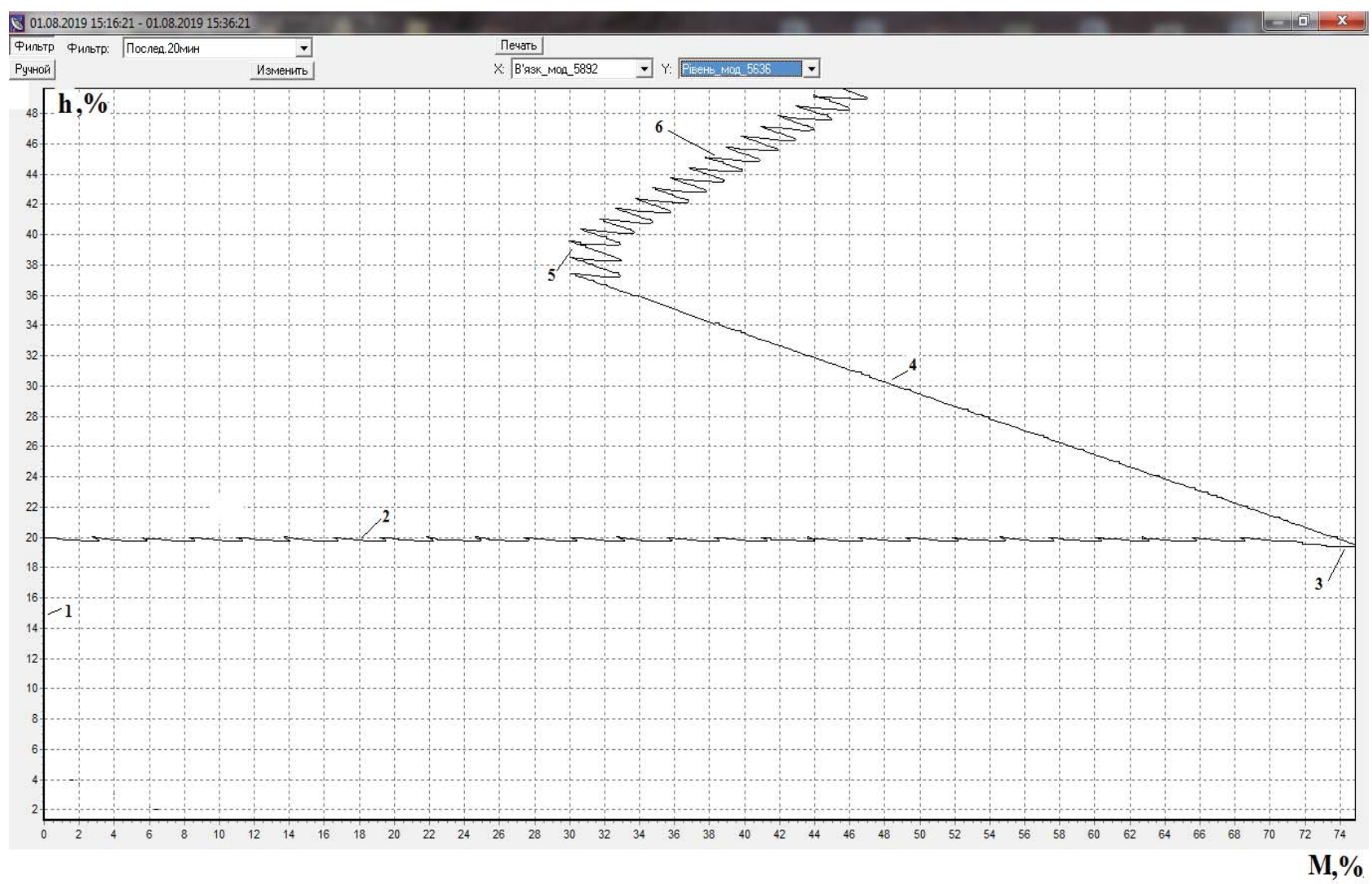

Рис. 5 - Діаграма процесу варки продукту у ВА на стадіях: 1 - набор ВА; 2 - згущення; 3 - «заводка» цукрової пудри; 4 - перша глибока підкачка; 5 - формування кристалу; 6 - початок зростання кристалу

Вид основної екранної форми оператора-варщика за результатами моделювання, зокрема закінчення стадії зростання кристалу у ВА та закінчення варки наведено на рис. 6. 


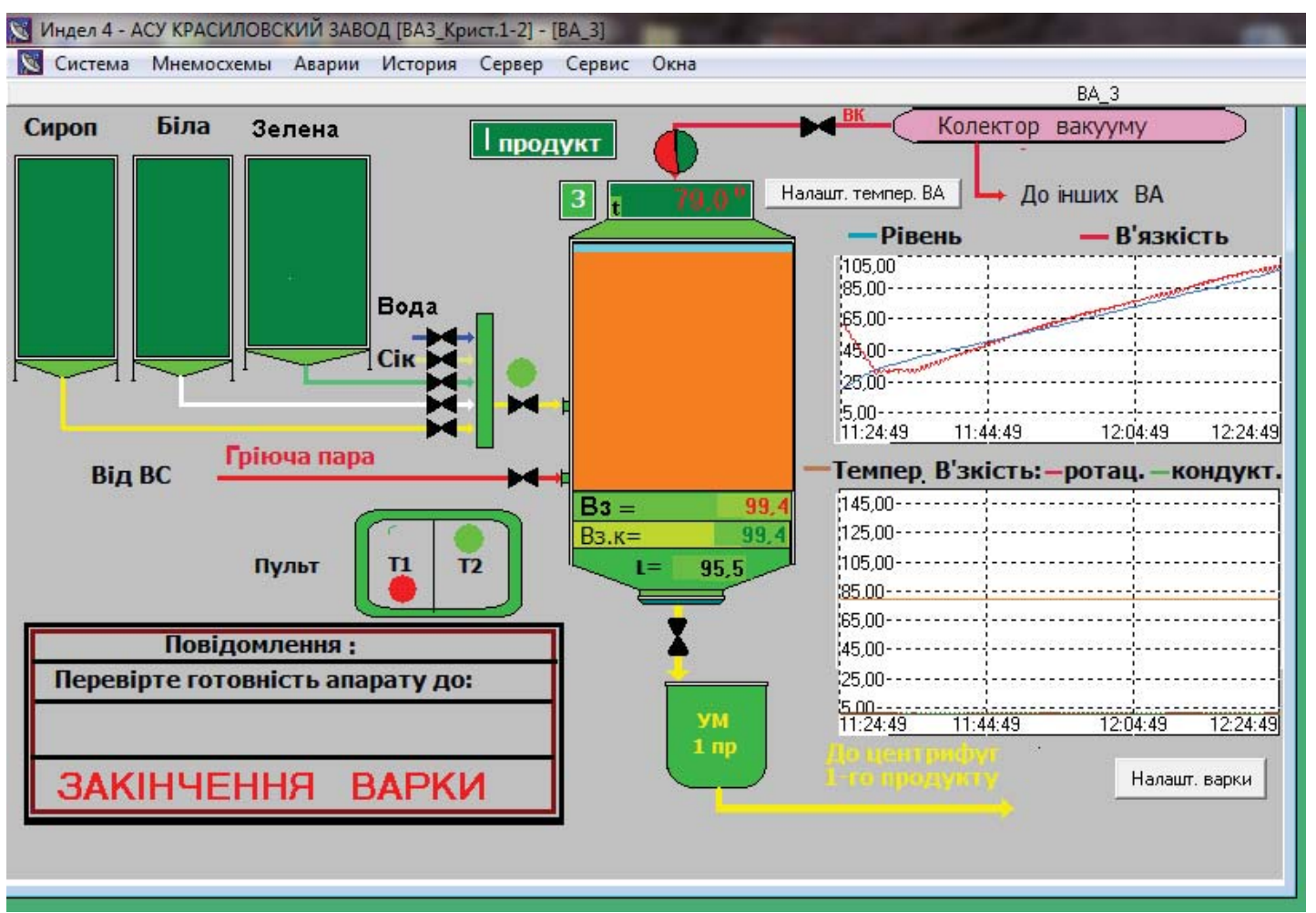

Рис. 6 - Основна екранна форма АРМ оператора-випарщика на стадіях: закінчення зростання кристалу у ВА та закінчення варки

Для цих етапів отримана під час моделювання діаграма (параметричний графік) має вигляд як на рис. 7.

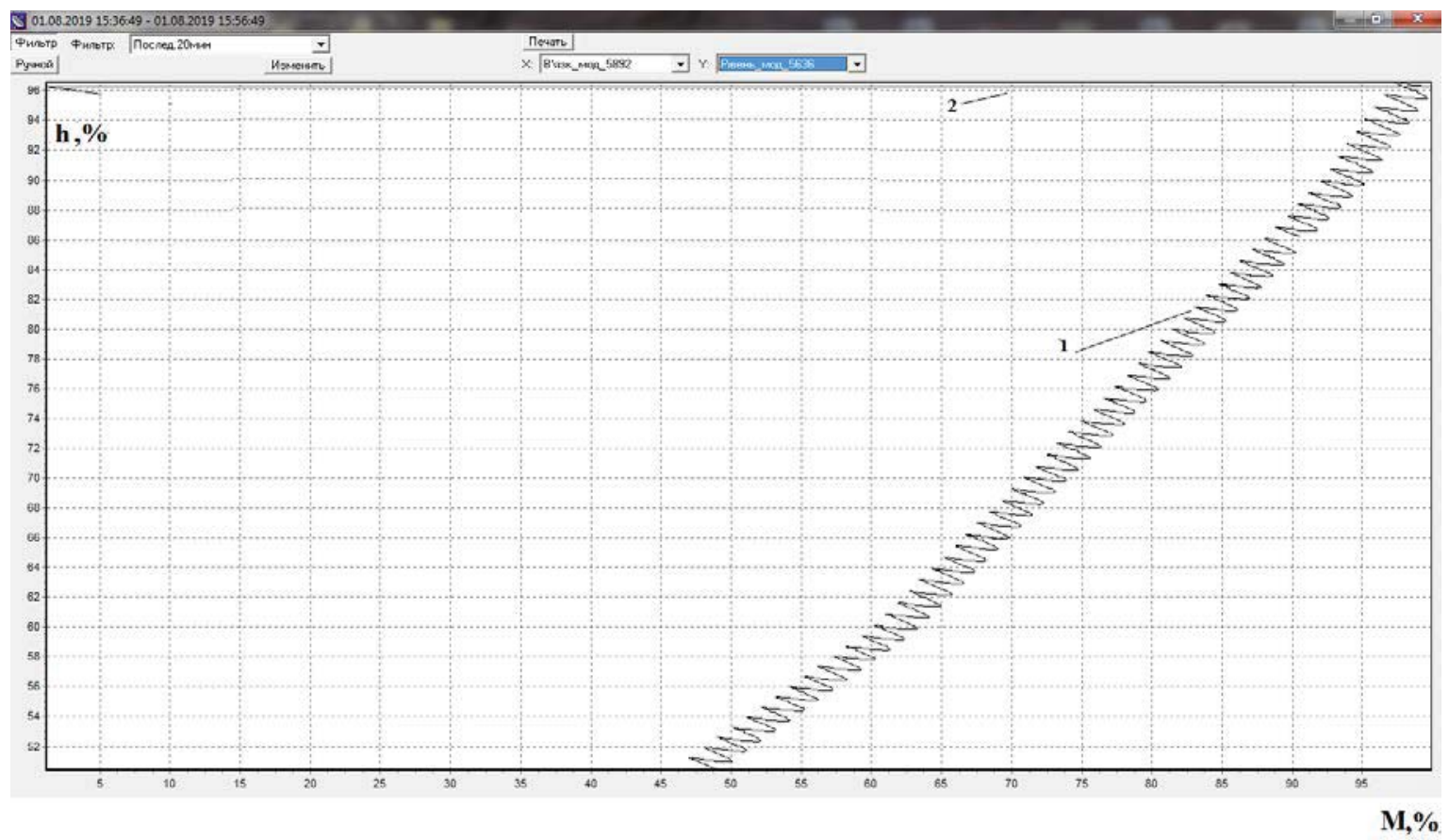

Рис. 7 - Діаграма процесу варки продукту у ВА на стадіях: 1 - закінчення зростання кристалу у ВА та 2 - закінчення варки

Часовий графік за результатами моделювання процесу керування варки утфелю у ВА отриманий за цикл засобами SCADA-системі «ІНДЕЛ» наведено на рис. 8. 


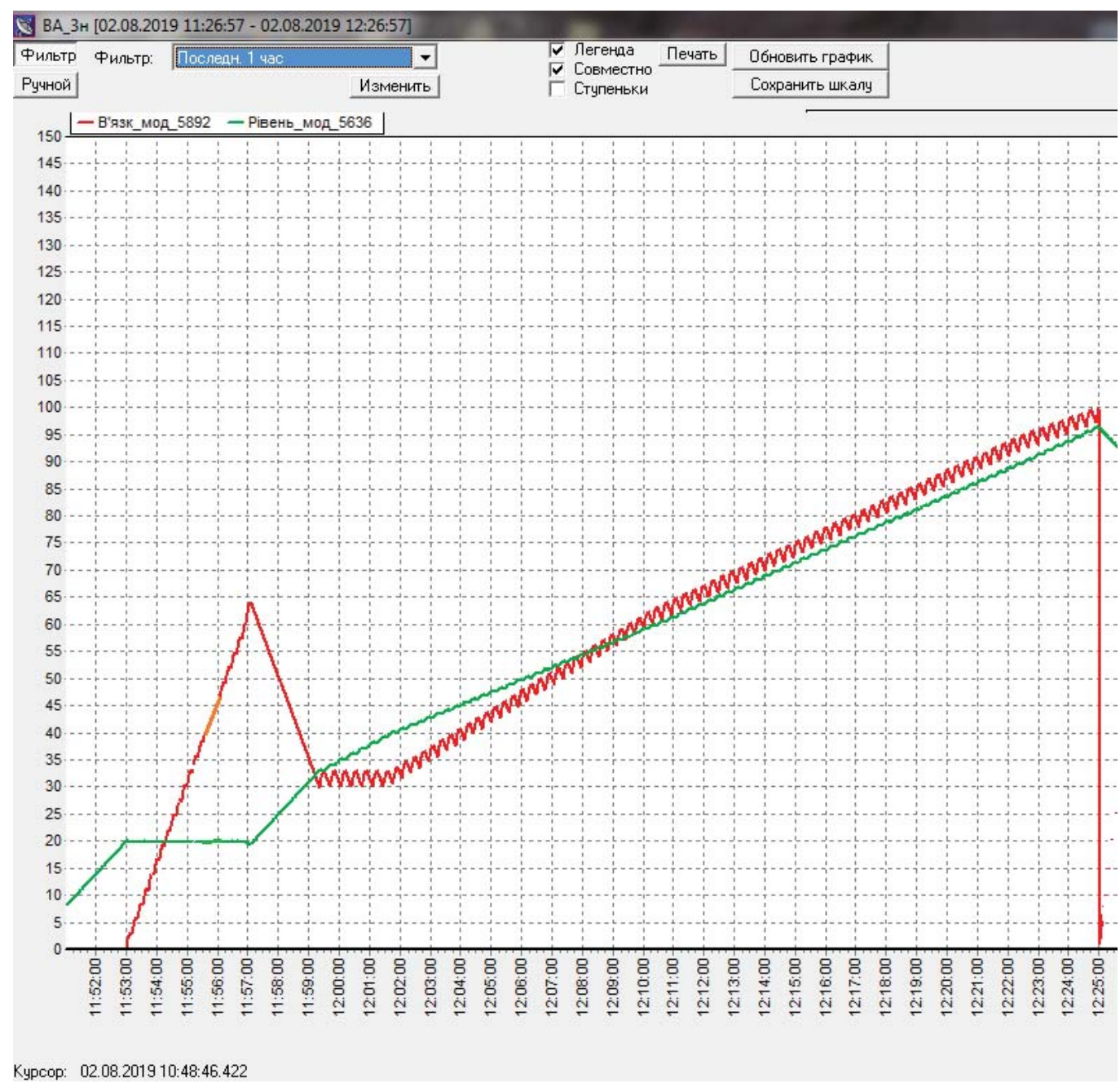

Рис. 8 - Часовий графік за результатами моделювання процесу керування варки продукту в ВА, отриманий за цикл варки утфелю

\section{Обговорення результатів}

Отримані результати проведеного дослідження дозволяють зробити висновки про працездатність розробленої САК процесом варки утфелю у ВА періодичної дії. Складені спрощені моделі ОК (BA) за каналами $\mathrm{U}_{1} \rightarrow>\mathrm{H}$; $\mathrm{U}_{1} \rightarrow>\mathrm{M} \epsilon$ достатньо адекватними для цілей дослідження, тому що вони вірно відображають процеси накопичення та випарювання продукту у вакуум-апараті. Ступень їхньої точності не має вирішального значення для оцінювання працездатності САК. Проведення моделювання процесів керування процесом у середовище програмування мікропроцесорного контролера, на базі котрого буде реалізовано APM, з використанням конкретної SCADA-системи, що буде задіяна в промисловій САК, - визнано доцільним рішенням. Традиційне моделювання керування технологічними процесами в середовище Matlab/Simulink доцільно використовувати у випадку неможливості використання промислових технічних та програмних засобів, і не раціонально за наявністю відповідних засобів.

За результатами дослідження були сформульовані рекомендації щодо доцільності використання розробленої програми варки утфелю в промисловій реалізації АРМ оператора-варщика на базі технічних і програмних засобів вітчизняного виробництва.

Промислова САК була реалізована в складі автоматизованої системи керування продуктового відділення Красилівського цукрового заводу, де були проведені ії виробничі випробування в сезон 2018/2019 років. В створеній системі був використаний промисловий комп'ютер ARK-3403-D6A1E/BTO2 із встановленою операційною системою XP E (MS Windows Embedded). Застосування промислового комп'ютера було обумовлено складними умовами повітряного середовища операторського пункту (ОП) продуктового відділення, а саме високою температурою та підвищеною вологістю. Для зменшення цих шкідливих факторів як для оператора, так і для технічних засобів в ОП використана примусова вентиляція. На рис. 9 наведено фото промислового АРМ, котре було зроблено напередодні промислового випробування впровадженої САК. 


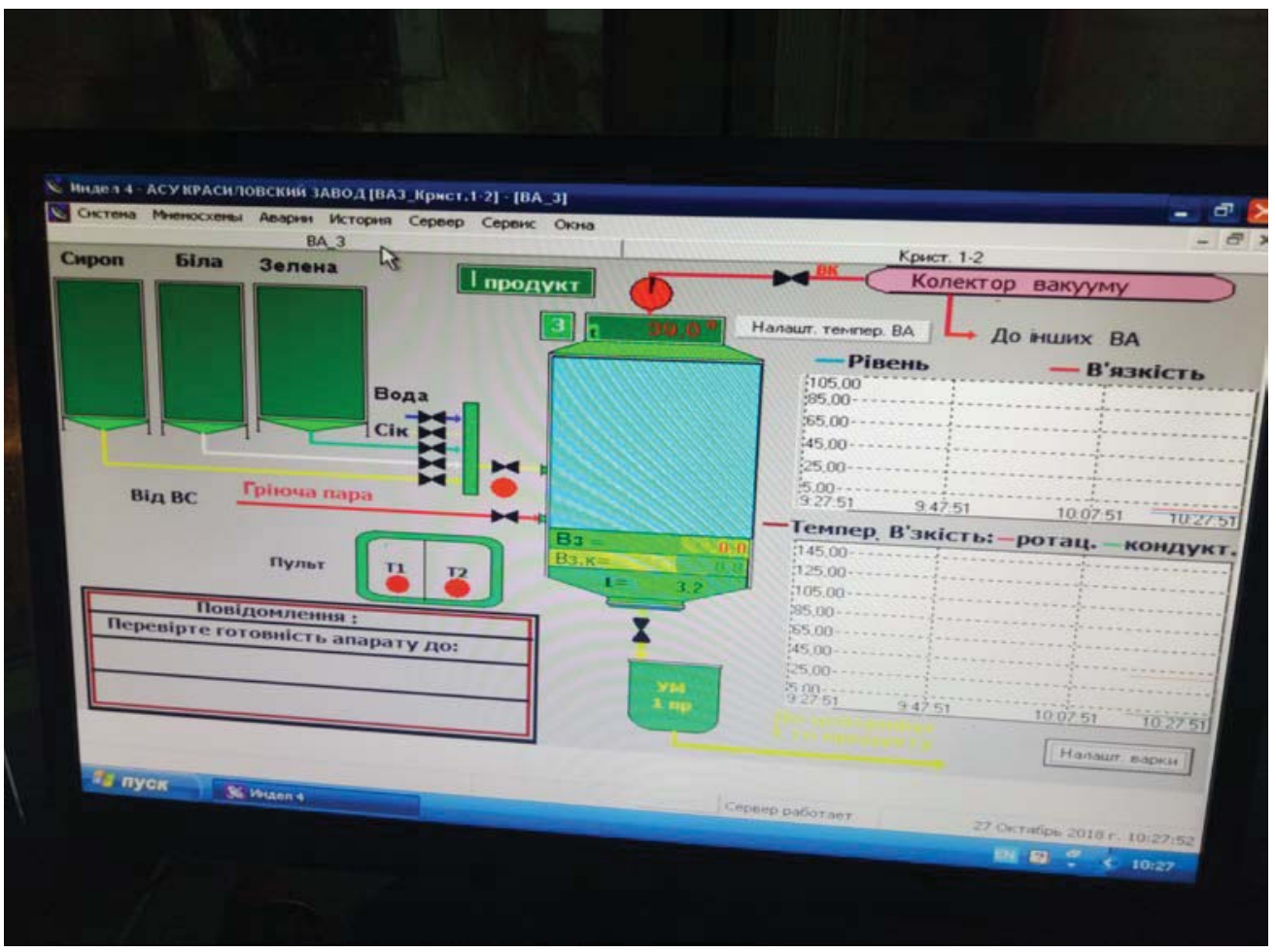

Рис. 9 - Фото з монітора промислового АРМ оператора-варщика

Промислові випробування показали працездатність розробленої САК. При цьому, проведені варки із використанням розробленої програми керування дозволили отримати утфель 3 потрібною якістю кристалів та тривалістю загального циклу його уварювання.

Подальші дослідження будуть спрямовані на визначення метрологічних характеристик кондуктометру, що встановлений у ВА разом із ротаційним віскозиметром для проведення порівняльного аналізу результатів вимірювання консистенції утфелю. Також, у період експлуатації потрібно дослідити взаємозв'язки керованих змінних, в тому числі тривалості циклу, з температурою (розрідженням) у ВА для пошуку оптимальної програми зміни температури в ВА на різних етапах програми уварювання утфелю та з використанням вихідних розчинів різного складу. У процесі таких досліджень треба також уточнити деякі індивідуальні характеристики ВА, на котрому проводяться роботи.

\section{Висновки}

Проведені передпроєктні дослідження з використанням методів імітаційного моделювання на спеціалізованому стенді, котрий було обладнано промисловим устаткуванням: контролерами та регуляторами, комп’ютером з SCADAсистемою «ІНДЕЛ», українського виробництва, дозволили розробити комплекс технічних рішень, що забезпечує успішну експлуатацію АРМ оператора-варщика в складі існуючої автоматизованої системи керування продуктового відділення цукрового заводу. Проведені промислові випробування підтвердили працездатність розробленої САК та дозволили визначити подальші напрямки досліджень.

Основна складова ефективності системи полягає в зменшенні питомих витрат енергоносіїв та підвищенні якості готового продукту.

Технічні і програмні засоби Українського виробництва забезпечують точність підтримання регламентів ведення процесу, досить комфортні умови праці, як оперативному персоналу, так і технічним керівникам підприємства для аналізу технологічних процесів.

Виконаний комплекс досліджень дозволяє зробити висновок про доцільність продовження робіт із модернізації систем керування підприємства, використовуючи принцип проєктування АСКТП - «знизу вгору», а також наведені методи й підходи до прийняття основних технічних рішень.

\section{Список використаних джерел}

[1] Жуковський Е.Й. Багаторівнева АСУТП цукрового заводу/ Е.Й. Жуковський, Ю.М. Скаковський, В.Д. Вітвицький, А.В. Бабков//Докл. 18 міжнар. конф. $з$ автоматичного управління „АВТОМАТИКА-2011” 28-30 вересня 2011, Львів, Україна, -Львів: Вісник НУ «Львівська політехніка», 2011 - С.256-257. 
[2] Современные технологии и оборудование свеклосахарного производства. В двух частях. Часть $2 /$ В.О. Штангеев, В.Т Кобер, Л.Г. Белостоцкий, Н.И. Штангеева и др. - Киев: Цукор України, 2004. - 320 с.

[3] АC СССР № 1318834, кл. G 01 N 1/10, Устройство для заводки кристалла и отбора пробы из вакуум-аппаратов сахарного производства/В.В. Пименов, А.О. Полторак, Ю.М. Скаковский; заявитель Всесоюзный проектноконструкторский и научно-исследовательский институт автоматизации пищевой промышленности Научнопроизводственного объединения "Пищепромавтоматика" - Опубл.: 07.03.1992, Бюл. № 9,1992 г. - 5 с

[4] Скаковский Ю.М. Автоматизированная система управления технологическими потоками и производительностью сахарного завода [Текст]:/диссертация на соискание ученой степени кандидата технических наук: 05.13.07/ Ю.М. Скаковский.- Одесса, 1987.- 319 с.

\title{
References
}

[1] E. Zhukovskyj, Yu. Skakovskyj, V. Vytvyczkyj and A. Babkov, “Bagatorivneva ASUTP czukrovogo zavodu”, Dokl. 18 mizhnar. konf. z avtomatychnogo upravlinnya “AVTOMATYKA-2011” 28-30 veresnya 2011. Ukrayna: Lviv: Visnyk NU “Lvivska politexnika”, pp. 256-257, 2011

[2] Sovremennye tekhnologii i oborudovanie sveklosakharnogo proizvodstva. V dvukh chastyakh. Chast 2. V.O. Shtangeev, V.T Kober, L.G. Belostoczkij, N.I. Shtangeeva i dr. Kiev: Czukor Ukrayini, p. 320, 2004.

[3] AS SSSR № 1318834, kl. G 01 N 1/10, Ustrojstvo dlya zavodki kristalla i otbora proby iz vakuum-apparatov sakharnogo proizvodstva. V.V. Pimenov, A.O. Poltorak, Yu.M. Skakovskij; zayavitel Vsesoyuznyj proektnokonstruktorskij i nauchno-issledovatelskij institut avtomatizaczii pishhevoj promyshlennosti Nauchnoproizvodstvennogo obedineniya "Pishhepromavtomatika". Opubl.: 07.03.1992, Byul. № 9, p. 5, 1992.

[4] Yu. Skakovskij, Avtomatizirovannaya sistema upravleniya tekhnologicheskimi potokami i proizvoditelnostyu sakharnogo zavoda [Tekst]:/dissertacziya na soiskanie uchenoj stepeni kandidata tekhnicheskikh nauk: 05.13.07/ Yu.M. Skakovskij. Odessa, p. 319, 1987.

УДК 004.93

\section{ІНФОРМАЦІЙНА СИСТЕМА ДЛЯ ДОПОМОГИ ФІНАНСОВИМ УСТАНОВАМ У ВИЗНАЧЕННІ КРЕДИТОСПРОМОЖНОСТІ КЛІЕНТІВ}

\author{
Шпинковський О.А. ${ }^{1}$, Шпинковська M.І. ${ }^{2}$, Голобородько В.В. ${ }^{3}$ \\ 1,2,3 Одеський національний политехнічний університет, м. Одесса, Україна \\ ${ }^{1,2}$ K. т. н., доцент, ${ }^{3}$ бакалавр \\ ORCID: ${ }^{1}$ 0000-0002-7000-0327, ${ }^{2}$ 0000-0003-1679-6341 \\ E-mail: ${ }^{1}$ csonpu@ukr.net, ${ }^{2}$ mis-s@ukr.net
}

Copyright (C) 2018 by author and the journal “Automation technologies and business - processes. This work is licensed under the Creative Commons Attribution International License (CC BY). http://creativecommons.org/licanses/by/4.0

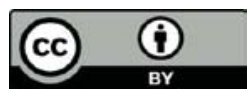

ONAFT

Open Access

DOI:

Анотація: У роботі підкреслено важливе місие у діяльності фінансових установ їх спроможність надавати якісні послуги юридччним та фізичним особам в отриманні кредитних позик. Розроблювальна інформаційна система надасть можсливість контролю роботи та керування записами користувачів системи. Завдяки ї̈ використанню банківські установи зможуть автоматизувати оцінку кредитоспроможності та уникнути небажаних ризиків та 